\title{
TRANSFORMASI UPACARA BELIAN KE DALAM TARI GITANG PASER
}

\author{
Oleh: Jumiati \\ (Pembimbing Tugas Akhir : Dra. M. Heni Winahyuningsih, M. Hum dan Dra. Budi Astuti, M.Hum) \\ Jurusan Tari Fakultas Seni Pertunjukan, Institut Seni Indonesia Yogyakarta \\ Alamat Emai : uumi.ati92@gmail.com
}

\begin{abstract}
RINGKASAN
Upacara Belian merupakan ritual pengobatan, membayar hutang, dan pembersihan kampung yang terdapat di Kabupaten Paser. Upacara Belian ini dilatar belakangi oleh sistem kepercayaan terhadap kekuatan-kekuatan gaib. Inti upacara Belian berupa gerak-gerak dan mantra-mantar. Gerak yang dihadiran pada upacara Belian ini menimbulkan inspirasi bagi seorang seniman bernama Irusmiati untuk mentransformasikan upacara Belian menjadi tari Gitang Paser.

Gerak dalam tari Gitang ini terinspirasi dari dua motif gerak yang dilakukan oleh Mulung yaitu perambut (gerak lambat), kerkesek (gerak cepat) serta bunyi gitang. Kedua unsur ini dikembangkan dalam irama, ritme dan penggunaan tenaga sehingga menjadikannya lebih dinamis

Untuk mengtahui aspek apa saja yang bertransformasi pada upacara Belian ke dalam tari Gitang Paser maka peneliti menggunakan konsep yang dikemukaka $\mathrm{n}$ oleh Djoharnurani yang mengemukakan bahwa proses transfomasi dapat dilalui dalam tiga tahap yaitu; 1) tahap pemahaman dan penghayatan makna; 2) tahap resepsi; dan 3) tahap tindak resepsi. Pada butir pertama adalah pemahaman dan penghayatan makna terhadap nilai-nilai yang ditransformasikan. Butir kedua adalah resepsi yang berarti penerimaan memang salah satu aspek yang ada dalam proses transformasi. Kemudian pada aspek tindak resepsilah transformasi membawa rangsangan idesional atau gagasan untuk membuat suatu yang baru. Maka melalui dari tiga tahap ini lah hasil transformasi antara upacara Belian dan tari Gitang Paser dari aspek rasa, bentuk, dan makna masing-masing bisa berubah, masih nampak ataupun menjadi samar-samar.
\end{abstract}

Hasil analisis di atas menunjukkan adanya suatu perubahan bentuk penyajian, makna serta fungsi upacara Belian ke dalam tari Gitang. Hasil yang didapat memberikan nilai yang bersifat mengembangkan. Salah satu pengembangan yang dapat dilihat dari bentuk penyajian yaitu gerak, gerak pada upacara Belian lebih sederhana hanya menggunakan dua motif yaitu perambut dan kerkesek ketika berubah maka gerak tersebut lebih dinamis karena memiliki berbagai macam motif. Pengembangan yang terjadi pada bentuk penyajian memberikan dampak perubahan pula pada 
fungsi. Fungsi pada upacara lebih pada ritual pengobatan ketika berubah menjadi tari Gitang fungsi tersebut sebagai hiburan semata tanpa meninggalkan suasana magis. Ketika bentuk dan fungsi berubah mengakibatkan perubahan makna yang terjadi pada tari Gitang yaitu hilangnya kepercayaan masyarakat setempat terhadap upacara Belian.

\section{Kata kunci : transformasi, mulung, gitang, belian.}

\section{ABSTRACT}

Belian ceremony is a ritual of treatment, debt repayment, and cleaning of villages located in Paser District. This Belian ceremony is based on a belief system of supernatural powers. The core of the Belian ceremony is in the form of movements and mantras. The movement attended at this Belian ceremony inspired an artist named Irusmiati to transform the Belian ceremony into a Gitang Paser dance. Motion in Gitang dance is inspired by two motive motifs performed by Mulung that is perambut (slow motion) kerkesek (fast motion) and the sound of gitang. It is developed in rhythm, rhythm and use of power making it more dynamic.

To know what aspects are transformed at Belian ceremony into Gitang Paser dance then the researcher uses the concept proposed by Djoharnurani which shows that the process of transfomation can be passed in three stages that is 1) Stage of understanding and appreciation of meaning 2) the reception stage and 3) stage of action. In the first point is the understanding and appreciation of the meaning of values that are transformed. The second point is acceptance which means acceptance is one of the aspects that exist in the transformation process. Then on the aspect stage of action transformation brings about an ational stimulus or an idea to create a new one. So through these three stages is the result of the transformation between Belian ceremonies into Gitang Paser dance from the aspect of taste, form, and meaning of each can change, remain visible or become blurred.

The results of the above analysis indicate a change in the form of presentation, meaning and function of Belian ceremony into Gitang dance. The results obtained provide a value that is developing. One of the developments that can be seen from the form of motion presentation, motion at Belian ceremony is simpler by using only two motifs that is perambut and kerkesek When changed the motion is more dynamic because it has a variety of motives. The development that occurs in the form of presentation gives effect to changes also on the function. The function at this 
ceremony is more on the treatment ritual when it transforms into a Gitang dance function as a mere entertainment without leaving the magical atmosphere. When the form and function change resulted in a change of meaning that occurred in Gitang dance that is the loss of local belief in Belian ceremony.

Key words : transformasi, mulung, gitang, belian

\section{PENDAHULUAN}

Belian merupakan upacara pengobatan tradisional, yang dipercaya dapat menyembuhkan penyakit tertentu dengan cara berkomunikasi dengan roh-roh atau mahkluk tertentu. Penyakit yang disembuhkan bukan penyakit yang biasa, contohnya sakit yang tak kunjung sembuh atau tak kunjung sadar, yang dalam bahasa medis dikatakan sebagai koma berbulan-bulan. Masyarakat Paser percaya bahwa suatu penyakit yang diderita oleh seseorang yang disebabkan oleh kekosongan jiwa sesaat, sehingga tubuhnya dimasuki oleh makluk gaib atau kekuatan tertentu yang menyebabkan manusia tersebut mendapatkan penyakit. Penyakit tersebut dapat disembuhkan oleh dukun atau disebut Mulung, dengan cara memanggil jiwa manusia tersebut agar kembali ke dalam tubuhnya. Proses pengobatan tersebut selain mempergunakan ramuan obat yang terdiri dari daun Serembolum dan Tepung tawar. Diperlukan seorang dukun atau Mulung yang bergerak dengan cara yang khas dan mengucapkan mantra untuk mengusir roh-roh jahat. Dukun atau Mulung tersebut mengenakan gelang atau disebut dengan gitang sebagai salah satu media yang dipergunakan untuk mengusir roh jahat. Di sajikan dalam bentuk upacara Belian.

Upacara Belian masih banyak dilakukan oleh suku Paser yang berdomisili di Kabupaten Paser. Sebetulnya tidak ada konsep tarian oleh suku Paser dalam upacara Belian, tetapi merupakan bentuk upacara sakral sebagai media untuk berkomunikasi antara dukun atau mulung dengan makluk super-natural, yang pelaksanaannya mengandung unsur gerak yang artistik sebagaimana layaknya sebuah gerak tari.

Seni tari memiliki kekuatan komunikatif. Ia tumbuh dari kehidupan dan merefleksikan kehidupan itu sendiri. Dengan demikian praktek upacara Belian dapat dikatakan sebagai upacara sakral yang berfungsi sebagai media komunikasi yang disampaikan dalam bentuk materi berunsur seni. Hal ini menjadikan ketertarikan seorang seniman untuk berkarya seni berdasarkan aktivitas 
upacara belian, sehingga lahirlah tari Gitang Paser yang kemudian akrab dipertunjukkan dalam berbagai kesempatan.

Belian yang semula dikenal sebagai upacara ritual berkembang menjadi tari Gitang Paser. Pertama-tama tari Gitang Paser digarap tahun 2010 oleh Irusmiati, karena keinginannya untuk berkarya tari berdasarkan bentuk ritual menjadi suatu bentuk tarian dalam sajian pertunjukan. Jadilah Tari Gitang yang digarap dengan pola gerak yang bervariasi dan ada unsur tekanan tertentu agar bunyi gelang terdengar kuat dan mempunyai unsur ritme yang sama dan mempunyai kesatuan irama, dan gerak sederhana terlihat dinamis akibat timbulnya bunyi gelang rampak dipadu dengan gerak lincah dan kuat dalam disain yang lebih variatif.

Hal ini sangat berbeda dengan bunyi yang ditimbulkan dari gelang yang dipergunakan oleh Mulung dalam upacara Belian. Bila dalam upacara Belian kesan magis, dan mitis lebih kuat, maka dalam tari Gitang Paser kesan yang sangat menonjol adalah tarian yang lincah, energik, dan dinamis.

Perkembangan yang ada pada ritual Belian yang kemudian menjadi tari Gitang Paser, menunjukkan adanya perubahan bentuk, makna dan fungsinya. Perkembangan ini mungkin membuat ada sesuatu yang berubah atau usaha-usaha untuk melahirkan bentukbentuk baru di dalam tari Gitang itu sendiri.
Dalam ilmu antropologi dan ilmu bahasa, perubahan semacam ini disebut dengan transformasi yaitu perubahan bentuk.

Tranformasi budaya menurut Echlos dan Sadily mempunyai arti perubahan bentuk, menjadi Proses transformasi tersebut menghasilkan unsur-unsur kebaruan, baik dari aspek gaya, rasa maupun makna, walaupun pada tingkat perubahan yang tak sama. Transformasi bukan hanya dimengerti sebagai perubahan bentuk saja tetapi juga mencakup pada perubahan pada fungsi dan makna tari itu sendiri. Hal tersebut relevan dengan fenomena yang terdapat pada upacara Belian yang ditransformasikan menjadi tari Gitang Paser.

\section{Transformasi Upacara Belian pada} Tari Gitang Paser

\section{Transformasi Bentuk Penyajian}

R.M. Soedarsono menegaskan bahwa pengkonseptualisasian pertunjukan sebagai sebuah fenomena yang otonom serta merupakan entitas yang multilapis. Sebuah pertunjukan merupakan perpaduan antara berbagai aspek penting yang menunjang seperti pelaku, busana, property, tempat pertunjukan, waktu pertunjukan, dan urutan penyajian Dyah Sri Mahasta (2011:15). Dari pendapat di atas maka peneliti akan merumuskan dan melihat Bentuk penyajian hasil dari transformasi upacara Belian ke dalam tari Gitang yang dapat dilihat secara 
nyata yaitu dari segi pelaku, kostum, proper ti, gerak, pola lantai, iringan, waktu dan tempat.

\section{a. Pelaku}

Pada upacara Belian pelaku atau tokoh utama yang terdapat pada upacara ini disebut oleh masyarakat setempat ialah Mulung. Patokan utama dalam upacara ini Mulung atau dukun harus lah berjenis kelamin laki-laki dan berumur 40 tahun ke atas karena pada hakekatnya alasan terpilih sebagai laki-laki dan berumur 40 tahun ke atas adalah karena masyarakat setempat mempercayai bahwa laki-laki yang berumur 40 tahun lebih lama dan lebih permangalaman dalam memahami isi dan mempelajari kandungan yang terdapat pada upacara Belian, contohnya dalam mempelajari mantra-mantra, berpuasa mutih, serta memahami betul nama-nama yang terdapat pada sesajen dan proerti yang digunakan.

Mulung lak-laki dianggap lebih kuat dalam menerima segala syarat yang akan di laksanakan walaupun gerak yang dilakukan tanpa menngunakan tehnik kepenarian karena konteks kegunaan dalam gerak Mulung diperuntukan sebagai upacara ritual dengan tujuan gerak yang dilakukan akan menimbulkan efek bunyi gitang sehingga rohroh yang dipanggil mendengarkan serta dapat menyukai kehadirannya.

Hal ini lah menjadi inspirasi penata tari, Irusmiati kemudia menuangkan hasli dari penghayatannya dalam melihat upacara Belian yang mentransformasikan ke dalam tari Gitang. Pemilihan pelaku dalam tari Gitang yang ia garap menggunakan pelaku berjenis kelamin perempuan berusia sekitar 17 tahun ke atas, alasan ia mentranformasikan dari pelaku berjenis kelamin laki-laki dan berunur 40 tahun dalam upacara Belian kemudian ia menggatikan dengan wanita yang berumur 17 tahun ke atas.

Dalam konteks seni pertunjukan dan dalam seni tari, perempuan dapat melakukan gerakan-gerakan feminim karena memang benar adanya gerak yang digarap irusmiati bersifat gerak yang lebih feminim, untuk pemilihan berumur 17 tahun ia mengatakan bahwa pada umur 17 tahun ke atas penari dapat melakukan tehnik-tehnik yang ia inginkan dan melakukan sebuah gerak tari yang menggunakan tehknik dengan olah tubuh yang ekstra dan dengan tehnik-tehnik tarian yang harus dipahami, dipelajari serta proses olah tubuh dalam rentan waktu cukup lama yang tidak terdapat pada Mulung.

Hasil dari pengamatan dan pemaparan di atas sangat terlihat jelas proses yang dilalui antara pelaku Mulung ketika berubah menjadi pelaku dalam tari Gitang menggunkan proses menuju ke tempat yang berbeda, salah satu contoh yang dapat kita lihat adalah proses menjadi pelaku dalam Belian yaitu Mulung melakukan syarat di antaranya, memahami 
mantra-mantra, berpuasa mutih, serta memahami betul nama-nama yang terdapat pada sesajen dan proerti yang digunakan. Kemudian ketika ia bertransformasi ke dalam tari Gitang proses yang terdapat pada upacara Belian tidak dipergunakan lagi menuju pelaku dalam tari Gitang, proses yang dilalui oleh pelaku tari Gitang adalah dengan olah tubuh yang ekstra dan dengan tehnik-tehnik tarian yang harus dipahami, dipelajari serta proses olah tubuh dalam rentan waktu cukup lama yang tidak terdapat pada Mulung.

\section{b. Kostum}

Dalam sebuah upacara Belian kostum yang dikenakan sangatlah sederhana. Penampilan pada upacara Belian, Mulung hanya menggunakan kain sarung atau ulap dan tidak menggunakan pakaian lainnya untuk menutupi tubuh bagian atas.

Kostum yang dikenakan Mulung pada upacara Belian dibuat dengan maksud tertentu yang mengandung filosifi dan tradisi pada upacara Belian. Adapun yang digunakan Mulung pada upacara Belian ialah mengalungkan sambaing sambit yang terdiri dari gigi taring dan kuku binatang digunakan dileher dengan dililit menyilang hingga ke belakang badan, ulap atau sarung digunakan mulung bagian bawah biasanya berwarna putih melambangkan kesucian, kuning melambangkan tingkatan atau derajat sesorang Mulung dan merah melambangkan keberanian.
Kaidah-kaidah ini sudah ditetapkan oleh seorang Mulung dan kepala adat setempat.

Selanjutnya Mulung mengenakan siek yaitu ikat pinggang yang menyimbolkan sopan santun yang digunakan seperti menggunakan sabuk, juntaian berada di samping paha. Laung atau udeng digunakan seperti menggunakan peci atau kopiah, biasa disebut ikat kepala berwarna merah yang melambangkan kewibawaan, tingkatan tinggi dan ahli dalam melakukan upacara.

Hal di atas menjadi pemicu inspirasi yang akan dilakukan Irusmiati dalam mengubah atau mentransformasikan kostum yang ada pada upacara ini dengan menyesuaikan garapan yang ia buat. Menurut ia tata busana dalam suatu peenyajian sangat penting, untuk memperjelas karakter penari. Kostum dan tata busana yang ideal adalah yang disesuaikan dengan bentuk dan wujud dari tari yang ditampilkan. Dengan mempetimbangkan pula. Bagaimana tidak mengganggu penari dalam melakukan gerak.

Sehingga timbul suatu idesonal dari penata tari mengambil bentuk dan warna yang terdapat pada tari Gitang ini. Kostum yang digunakan dalam tari Gitang paser, memakai kostum atasan berwarna coklat muda dengan ukiran motif kalimantan timur maksud dari warna yang digunakan tidak ada keterkaitan dengan kostum yang digunakan pada Mulung melaikan timbul karena melihat pergerakan 
yang dilakukan oleh para penari gitang dan penyesuaian warna kulit agar efek dari gerak lebih terlihat dan motif yang digambarkan akan lebih menonjol, ini menjadi salah saatu alasan penata tari mengambil warna tersebut.

Untuk kostum bagian bawah penata tari mempergunakan dua warna dalam yaitu satu berwarna merah dan satu berwarna hitam dengan motif Kalimantan Timur dan mempunyai belahan kanan dan kiri. Kedua dari bawahan ini dapat digunakan sesuai selera dari koreografi sendiri. Terdapat motif kalimaantan dalam penggunaan bawahan ini Untuk motif yang terdapat pada dan bawahan, tidak ada maksud tertentu tetapi motif tersebut diperuntukan sebagai penambah keindah pada kostum.

Corak yang dipilih dalam tari Gitang tidak menggunakan kaidah-kaidah seperti pada kostum Belian, yang masih berepegang teguh pada tradisi leluhur dengan ketetapan warna yang telah ditentukan. Pada tari Gitang warna yang dipilih adalah warna-warna yang telah disesuaikan dengan panggung, agar menambak keindahan semata serta kostum yang digunakan adalah pilihan yang nyaman untuk dibawa bergerak atau menari.

Setelah proses pelaku dan proses gerak yang berubah atau bertransformasi maka kostum dan tata busana dalam masing-masing garapan ikut berubah, dikarenakan pada upacara Belian perpegang teguh pada adat istiadat yang ditetapkan oleh kepala adat yang kemudian dipelajari dan disimpan oleh Mulung, hingga saat ini dalam upacara Belian kaidah-kaidah ini masih dijaga. Untuk perubahan yang terjadi pada tari Gitang hal ini ditetapkan oleh penata tari yang tidak berpegang teguh pada adat yang ditetapkan melaikan hanya kebutuhan pertunjukan. Agar penonton merasa nyaman dan aman ketika melihat pergerakan yang dilakukan oleh para penari gitang. Jadi inti dari proses tersebut dan perubahan tersebut ialah bereda tujuan dan orang yang mengatur maka suatu hal tersebut dapat berubah pula menjadi hal yang baru atau menghilangakannya sama sekali tergantung dari kebutuhan masing-masing.

c. Properti

\section{c.1. Gitang}

Properti adalah perlengkapan yang digunakan oleh penari yang bukan termasuk kostum. Properti tidak hanya sebagai komponen pelengkap dalam penyajian upacara maupun tari. Pada upacara Belian dan pada tari Gitang properti yang digunakan yaitu Gitang atau gelang.

Gitang yang dipakai oleh penari pada upacara Belian, memiliki bentuk seperti gelang pada umunya dan berwarna coklat dengan berat kurang lebih $1 \mathrm{~kg}$, terbuat dari campuran perunggu memiliki diameter $5 \times 5 \mathrm{~cm} .{ }^{1}$ Gitang ini digunakan pada tangan kita dua buah dan 
tangan kanan dua yang semuanya berjumlah 4 buah. Fungsi dari penggunaan gitang dalam upacara Belian ini ialah terdapat pada bunyi dari hasil pergerakan Mulung pada akhirnya bunyi yang dihasilkan dari gitang menurut masyarakat setempat sebagai pemanggil dan persembahan hiburan bagi roh-roh yang telah dipanggil. Selain sebagai sarana pemanggil roh-roh gitang dalam upacara Belian gitang ini juga berfungsi sebagai komando dalam upacara adat Belian. Suara yang dihasilakan sebagai penuntun gerakan Mulung dan pemain musik pengiring Belian, wawancara kai nyemat (24 juni 2016).

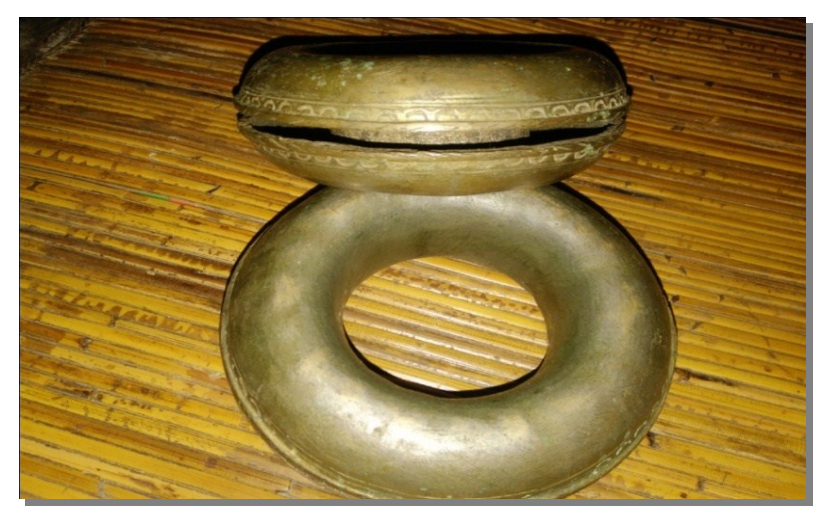

Gitang (Gelang) yang digunakan Mulung (Dok. Jumiati, 2016)

Salah satu identitas Mulung dalam upacara Belian ini menjadi inspirasi utama dalam mengubah atau mentransformasikan properti gitang, bahwa ia meyakini bunyi yang dihasilkan dapat dikembangkan kembali menghasilkan ritme dan dinamika yang dapat tercipta di dalam garapan penata tari.

Dari inspirasi yang ia dapatkan maka penata tari mengemas gitang dengan warna dan bentuk yang sama hanya ukuran yang lebih kecil, dimaksud agar para penari tidak keberatan dan tidak mengganggu pergerakan tangan penari dalam membunyikan gitang.

Setelah gitang ini dijadikan sebagai properti pada tari Gitang, maka bentuk dan ritme yang digunakan pada upacara Belian mempunyai irma dan ritme yang berbeda dengan ritme yang terdapat pada upacara Belian, pada tari Gitang irma dari gitang berfungsi sebagai penambah dan penanda ritme dan ketukan pada musik tari Gitang, menambah kesan ramai dan lebih meriah pada tarian ini. Tidak ada unsur magis seperti yang telihat pada upacara Belian.

d. Gerak

Gerak adalah unsur utama dalam tari, gerak meliputi bagian-bagian tubuh yang meliputi tangan, kaki dan tubuh secara keseluruhan. Gerak merupakan unsur pokok dalam diri manusia dan merupakan alat bantu dalam kehidupan manusia, untuk mengemukakan keinginan dan menyatakan refleksi spontan di dalam jiwa manusia.

Perinsip gerak-gerak yang dimiliki Mulung dalam upacara Belian terdapat pada dua unsur yaitu pada kaki dan tangan. Berikut pemaparannya

\section{d.1. Gerak Kaki}

Pada dasarnya gerak kaki yang terdapat dalam upacara adat Belian adalah gerakan yang sederhana dan berulang terus-menerus, 
menari didasari oleh adanya dorongan kebutuhan rohani yang menyangkut kepercayaan adat setempat. Semua gerak dalam upacara Belian tidak diciptakan sebagai gerak berurutan baku, semua gerak berirama lembut (perambut) dan lama kelamaan akan menjadi gerakan cepat yang disebut (kerkese) dan kaki sedikit diangkat berjinjit kemudian dihentakan sedikit demi sedikit.

Pertama, dinamakan gerakan perambut yaitu gerakan yang tempo iramanya lambat. Gerak ini melambangkan semangat untuk sebuah harapan baru dan memberi restu terhadap leluhur agar senantiasa diberi keselamatan bagi keluarga yang memberikan hajat. Dan gerakan ini menyimbolkan kesiapan dalam melaksanakan upacara adat Belian. Gerakan ini juga berfungsi sebagai pemanggil mahluk-mahluk halus yang diundang dalam pelaksanaan Belian. Kesiapan berarti siap dalam segala kondisi, siap dalam segala tata upacara, siap dalam segala lahir batin, wawancara Noryah (20 maret 2017). Kedua, gerakan kerkesek, merupakan gerakan dengan tempo irama yang cepat. Gerakan ini menyimbolkan sukacita, artinya dalam melaksanakan upacara adat ini seluruh pihak yang terlibat dalam upacara adat merasakan sukacita dan tidak merasa terbebani dengan adanya pelaksanaan upacara adat tersebut.

Penyelenggaraan upacara adat dengan rasa senang akan menghasilakan dampak yang baik. ketiga, dinamakan arangjuwata merupakan gerakan terakhir dalam rangkaian upacara adat Belian. Gerakan ini menyimbolkan rasa terima kasih kepada seluruh yang hadir. Ucapan terima kasih ini menunjukan kepada masyarakat yang sudah hadir dalam upacara adat dan kepada mahkluk halus yang juga ikut hadir dan diundang dalam rangkaian upacara, wawancara Noryah (20 Maret 2017). Karena hanya menggunkan tiga motif saja maka dikatakan gerak dalam upacara Belian sangat lah sederhana tetapi mempunyai aura yang berbeda, hal tersebut dikarenakan tujuan dari gerakan itu ialah sebagai pemanggil dan penghibur roh-roh yang ada di dalam upacara tersebut.

\section{d.2. Gerak Tangan}

Gerak pada upacara Belian memiliki nilai ritual dimaksudkan sebagai penghibur agar para roh leluhur hadir dengan adanya bunyi-bunyi dari gitang, gerak ini biasanya dilakukan dengan irama sedang dan cepat. Sambil menari-nari diiringi musik, kemudian Mulung membacakan mantra-mantra kepada mahkluk halus yang diundang dalam upacara adat Belian. Mulung berkomunikasi dengan menggunakan bahasa Paser halus dengan doadoa meminta permohonan sambil menyebut nama-nama penguasa air, tanah, udara, hutan.

Gerakan pada upacara ini tidak menggunakan tehnik yang khusus dan tidak menggunakan hitungan yang baku, gerakan ini 
tidak seritme dengan hitungan gerak tari pada umunya, tetapi gerakan ini adalah sebuah gerakan yang mengandung unsur-unsur komunikasi kepada roh-roh yang telah dibahas pada bab II.

Dari gerak-gerak di atas menjadi inspirasi oleh seorang penata tari, ia meyakinin bahwa gerak-gerak yang terdapat pada Mulung dapat dikembangkan lagi dan dituangkan ke dalam sebuah seni pertunjukan diberi nama tari Gitang. Transformasi ini kemudian dibuat oleh penata melalui tehnik-tehnik kepenarian yang telah diperhitungkan dengan cara olah tubuh dengan rentan waktu yang cukup lama. Menjadikan tiga motif sederhana yang terdapat pada gerak Mulung dapat diolah menjadi bermacam-macam motif gerak dengan hitungan baku.

Motif yang terdapat pada upacara Belian yaitu ngerkesek dan perambut yang telah disebutkan tadi berubah manjadi berbagai macam motif di antaranya ialah putar penggading, Tusuk gitang ke bawah, Lambai tangan gitang, dan lain-lainya, dapat dilihat pada bab bab III.

Kertika Gerakan pada Mulung ini bertransformasi tidak hanya tiga motif tersebut berubah melainkan unsur-unsur dinamika gerak pun menjadi berubah, semua ini dikarenakan tujuan yang terdapat pada upacara dan tari Gitang berbeda, dinamika gerak yang dilalui pada upacara Belian ialah mengnadung unsur-unsur magis sehingga dinamika dan aura yang timbul pun bersifat magis berbeda ketika ia sudah dikembangkan dan bertransformasi pada garapan kreasi baru yaitu tari Gitang, maka gerak tersebut diperuntukkan sebagai gerak penghiburan bagi masyarakat, agar masyarakat penonton mempunyai kegembiraan dan kesenangan dalam melihat suatu pertunjukan tari di kabupaten Paser ini.

\section{e. Pola Lantai}

Gerak tari pada upacara Belian memiliki pola lantai atau desain laintai yang dilalui oleh seorang penari atau pola lantai yang berbentuk garis-garis yang dibuat oleh formasi penari kelompok, Soedarsono penyelenggaraan gerak tari dalam Upacara Belian mengenal adanya desain atau pola lantai melingkar dan lurus. Pada dasarnya garis lurus memberikan kesan kesederhanaan tetapi kuat. Desain lantai lengkung yang berbentuk lingkaran mengandung maksud kekuatan tertentu. Desani lantai lingkaran pada upacara Belian mengandung unsur kekuatan magis, karena dianggap sebagai suatu upaya atau suatu hal yang tidak dapat memutuskan suatu kekuatan yang berada pada suatu lingkaran.

Pemahaman makna-makna di atas menjadi suatu penghayatan yang di lakukan oleh Irumsiati, bahwa pola lantai bisa diubah sebagaimana kebutuhan dari gerak-gerak penari. 
Pada perubahan gerak pada upacara Belian ke dalam tari Gitang berdampak pada perubahan pola lantai yang di lalui oleh para penari Gitang. Terdapat dua pola lantai di dalam upacara Belian yaitu pola lantai lurus dan melingkar dengan maksud dan tujuan yang telah dijelaskan di atas. Pola lantai sederhana ini kemudian ketika berubah alih maka pola lantai ini tersebut memiliki delapan belas pola lantai, maksud dari delapan belas pola lantai ini tidak hanya sebagai ekspresi ruang yang akan digunakan oleh koreografer, agar tidak mendapatkan kesan monoton dan mempunyai pormasi yang lebih nyaman bagi sang penari, adanya kontak saling mengisi antara penari satu dan penari yang lainnya.

Hal di atas tersebut adalah salah satu peristiwa transformasi yang berada di dalam pola lantai, terlihat jelas bawah perubahan dalam satu kemasan pola lantai yang berada wilayah ritual dapat berbeda jauh ketika peristiwa perubahan alih tersebut menjadi sebuah suguhan tari kreasi baru, karena tujuan utama dari pola lantai upacara Belian.

\section{f. Iringan}

Dalam upacara Belian iringan yang digunakan tidak memakai kaidah-kaidah tertentu irama yang dimainkan terus menerus dan melakukan pengulangan mengandung unsur sebagai pemanggil roh-roh halus dan seirama antara gerak dan musik kurang ditemukan, walaupun musik yang begitu ramai dengan menggunakan alat-alat musik begitu banyak, tetap iringan yang terdapat pada nadanada ini bernuansakan ketegangan bagi yang mendengar karena dengan suara gitang dari seorang Mulung yang tidak sejalan dengan ritme musik maka membuat musik tersebut semakin tidak menentu.

Dalam idesonal penata tari melihat dan mendengarkan iringan yang dibuat oleh pemusik di dalam upacara Belian membuat penata tari mencoba mengolah,merapikan, dan memadukan ritme-ritme agar sejalan dengan nada yang terdapat pada gitang sehingga mempunyai ketukan yang baku, dan mempunyai hitungan yang saling berkaitan antara musik, penari dan bunyi gitang.

Transformasi dari iringan yang terdapat pada upacara Belian ke tari Gitang ini sangat terlihat Nampak pada posisi ritme dan hitungan yang menjadi satu kesatuan ritme dalam sebuah gerak. Iringan yang terdapat pada upacara Belian dapat dilihat lebih banyak menggunakan pengulangan ketika bertransformasi maka musik pada tari Gitang kurang melakukan pengulangan dapat dikatakan lebih bervariasi antar iringan dan tari saling berirama.

g. Waktu

Dalam sebuah upacara Belian waktu atau durasi yang digunakan cukup panjang sehingga memakan waktu yang cukup lama atau waktu tidak terbatas. Upacara Belian 
dapat dilaksanakan dalam tiga hari, tiga malam sampai pada tiga puluh hari dan tiga puluh malam tergantung dari hajat yang di laksanankan, dengan tiap malamnya mempunyai tujuan dan maksud yang berbedabeda yang telah dijelaskan pada bab II. Durasi yang panjang ini membuat jenuh dan membosankan bagi penonton yang menyaksikan pertunjukan ini.

Melalu tangan penata tari mencoba mengubah kebosanan penonton tersebut dengan cara memperkecil durasi yang dituangkan melalui sebuah pertunjukan tari kreasi baru. Ketika transformasikan durasi yang digunakan dalam tari Gitang yaitu lebih singkat berkisaran dari 5 sampai 6 menit, dan waktu telah ditentukan antara penari, dan pendukung-pendukung lainnya, sesuai kesepakatan antar panitia.

Transformasi yang terdapat pada waktu ini dapat dilihat dari segi waktu yang pertama dapat dilihat dari segi durasi, pada upacara Belian durasi ini sangat panjang sehingga penonton merasakan adanya sebuah kejenuhan yang begitu menoton, ketika berubah alih durasi ini diperkecil menjadi 5 sampai 6 menit sehingga penonton yang melihat tidak meraskan kejenuhan yang berkepanjangan. Transformasi Pada upacara Belian yang kembali terlihat ialah pemilihan waktu pada upacara Belian ialah melakukan rundingan terlebih dahulu kepada yang bernazar sehingga ada tata aturan yang tidak boleh dilanggar ketika bertransformasi pelaku dalam pemilihan waktu adalah tidak melakukan rundingan kepada kepala adat, Mulung, atau pun kepada masyarakat yang ingin bernazar, tetapi penata tari berunding kepada panitia penyelenggara tari Gitang dan dapat dipentaskan kapan saja dan dimana saja tanpa adanya aturan seperti pada upacara Belian.

\section{Transformasi Makna}

Suatu pementasan karya tari, baik berlatar tradisonal maupun garapan baru pastilah mengandung makna-makna tertentu. Makna tersebut adalah sesuatu arti atau kisah yang ingin disampaikan oleh penata tari kepada penonton. Karena pada dasarnya penonton seni pertunjukan ingin mendapatkan dua hal, pertama kenikmatan visual, dan kedua adalah pemahaman makna di balik aspek visualnya.

Isi dalam sebuah makna hal yang tidak dapat dipisahkan, isi adalah maka atau arti yang menjelaskan tentang bentuk dengan segala aspek visualnya Sumaryono (2003:51).Isi tidak akan menjadi jelas jika bentuk garapannya belum maksimal diperkaya dengan simbolisasi, Sumaryono (2003:51) Dari pemaparan di atas jelas bahwa dikatakan antara bentuk, isi dan simbol saling mendukung dan saling berkaitan, maka dari itu penulis melihat transformasi dari ketiga hal tersebut, di atas telah dibahas untuk bentuk 
penyajian yang menjadi salah satu dasar dari tiga elemen tersebut. Sehingga di bawah ini akan di paparkan mengenai isi dan simbol hasil dari transformasi dari upacara Belian ke tari Gitang Paser.

a. Isi

Isi ceriata yang terkandung dalam upacara Belian di mana maknanya dari ritual ini agar dapat hidup bersama-sama dengan makhluk ciptaan-Nya dan manusia dengan makhluk lain (roh-roh halus), tidak saling mengganggu satu sama lain. Namun cerita yang mengandung makna tersebut semakin tekikis dan hampir menghilangkan karena dalam tari Gitang hanya berperan sebagai pelaku pementasan tari Gitang yang mana dalam pementasannya lebih mengutamakan mendapatkan materi dari pada menyampaikan pesan-pesan yang tersirat pada upacara Belian . Sehingga ketika sudah dalam seni pertunjukan makna isi dari upacara Belian berubah menjadi sebuah hiburan semata tanpa melihat isi dari cerita di upacara Belian.

\section{b. Simbolik}

Adanya kepercayaan pada benda-benda tua seperti lau lutung atau rumah-rumahan, dupa-dupaan berupa kayu yang dibakar menegluarkan asap, simbol-simbol yang terdiri melalui sesajen yang diyakini membawa dampak baik apabila dilaksanakan. Dengan melakukan kepercayaan tersebut seseorang berharap agar mendapatkan berkah dan selalu mendapatkan hal-hal baik. Namun kepercayaan itu mulai menghilangkan dari amsyarakat Paser sehingga dalam pementasan tari Gitang tidak lagi menggunakan sesajen, dupa, dan menyangkut sistem kepercayaan pada benda-benda tua. Sehingga tidak perlu menggunakan suatu kesepakatan yang ada di dalam tari Gitang.

\section{Transformasi Fungsi}

Dari penjelasan pada bab II Dalam ritual Belian jelas dapat dilihat fungsi dari upacara ini sebagai langkah mengusir roh-roh halus yang mengganggu ketentraman hidup manusia. Pelaksanaan yang dilakukan melalui suatu kesepakatan terlebih dahulu dengan syarat waktu, dan jam yang sudah disepakati dengan tempat, hari yang sudah ditentukan. Ketika pada tari Gitang, perubahan ini telah terlihat jelas yaitu ketentuan jam sudah tidak diperhitungkan lagi, dapat dipentaskan dimana saja dan kapan saja tanpa syarat-syarat yang terdapat pada ritual Belian, sehingga perubahan fungsi ini terjadi dari sebuah ritual pengusir roh-roh yang mengganggu berubah menjadi sebuah adegan hiburan untuk menghibur penontonnya. Selanjutnya perubahan fungsi dari alat musik yang awalnya musik ini diperuntukan untuk mengundang makhluk halus, yang namun dengan perkembangannya, alat musik berubah dan 
bertambah yaitu awalnya menggunakan gendang besar, gendang, tengkanong, lumbak, dan gong namun perkembangannya waktu membuat alat yang digunakan menjadi bertambah seperti adanya gambus 3 buah jimbe, suling, gong, dan gambang yang berfungsi sebagi penambah meriah bukan lagiberfungsi sebagi pengundang makhluk halus. Akibatnya adanya perubahan alat musik yang digunakan inilah orang yang bertugas melakukan do'a-do'a sebelumnya untuk keselamatan sudah tidak digunakan lagi. Selain itu, alat musik yang digunakan dalam tari Gitang sekarang menjadi alat musik biasa yang dahulunya dipandang menjadi alat musik yang mempunyai kekuatan magis dan tidak sembarangan untuk ditabuh.

\section{PENUTUP}

Berdasarkan hasil pembahasan terkait dengan transformasi upacara Belian ke dalam tari Gitang Paser, maka transformasi memiliki arti bahwa transformasi diandaikannya sebagai suatu proses peralihan total dari suatu bentuk menuju sosok baru yang akan mapan atau dengan arti lain perubahan. Proses transformasi selalu menghasilkan unsur-unsur kebaharuan, baik dari aspek gaya atau bentuknya, fungsi maupun maknanya walaupun pada tingkat perubahan yang tak sama. Ada tiga tahap dalam melihat hasil terakhir yang akan di dapat yaitu melalui tahap berikut: tahap pemahaman dan penghayatan makna, tahap resepsi dan tahap tindak resepsi.

Pada tahap tindak resepsilah Irusmiati mencoba untuk mengambil suatu inti sari yang terdapat pada upacara ini yaitu sebuah aktivitas yang dilakukan oleh seoang Mulung. Hasil resepsi ini lah menjadi sebuah rangsangan idesional atau gagasan untuk mrmbuat sesuatu yang baru, menimbulkan 
gagasan untuk mencari alternative-alternatif yang dapat menggambarkan atau setidaktidaknya memberikan kesa atau gambaran dari makna hasil resepsinya. Demikianlah hasil transformasi seni, khusunya pada upacara Belian ke dalam tari Gitang Paser dari aspek bentuk, makna dan fungsi masing-masing bias ataupun menjadi samar-samar, tetapi jelas akan muncul sesuatu yang baru karena hakekatnya transformasi sebenarnya adalah perubahan, sedangkan perubahan menumbuhkan kebaruan sehingga kebaruan dan tindak resepsi tersebut dapat dilihat dari berbagai aspek transformasi bentuk, transformasi makna, transformasi fungsi. Sehingga fenomena yang ditemukan dari penelitian ini semakin tenggelamnya nilai-nilai lama di dalam masing-masing makna, fungsi, dan bentuk penyajian dan sebuah upacara Belian. Tetapi pada sisi lain, tari Gitang memiliki daya jangaku yang jauh, lebih luas, serta memiliki nilai-nilai dan makna yang baru tetapi masih berada dalam cita rasa Belian.

Sehingga hasil yang didapat adalah membuktikan adanya hasil transformasi yang terjadi pada upacara Belian ke dalam tari Gitang Paser. Sehingga hasil dari transformasi itu sendiri dapat dilihat dari bentuk penyajian, makna serta fungsi mengacu pada buku yang ada. Ketika transformasi itu berjalan nilai dan hasil dapat dilihat bahwa semakin memudarnya dalam identifikasi bentuk, makna dan fungsinya yang nota bene semula adalah dari sebuah upacara ritual penghusir roh-roh jahat. Tetapi transformasi yang ditemukan dalam penelitian ini yakni transformasi yang bersifat mengembangkannya.

\section{DAFTAR SUMBER ACUAN}

\section{A. Sumber Tercetak}

Hadi, Y. Sumandiyo. 2014. Koreografi Bentuk Teknik Isi, Yogyakarta: B.P. ISI Yogyakarta.

Jaeni. 2013. Kajian Seni Pertunjukan Dalam Persepektif Komunikasi Seni, Bandung: IPB.

Jamil, Nizam. 1987. Upacara Tradisonal Belian Di Daerah Riau. Pekanbaru. Depdikbud.

Schechner, Richard. 2004. Performance Theory, New York and London: Routledge.

Sumaryono. 2003. Restorasi Seni \& Transformasi Budaya. Yogyakarta: Elkaphi (Lembaga Kajian Pendidikan dan Humaniora Indonesia).

\section{B. Nara Sumber}

Aji jamil, 55 tahun, pemangku adat dalam upacara Belian

Nyemat, 60 tahun, Mulung atau dukun dalam upacara Belian.

Muhidin, 45 tahun, Kades di desa Lempesu Kab. Paser 
Noryah, 58 tahun, ahli syah atau ahli cerita

Irus, 27 tahun, koreografer tari Gitang. 